\title{
Kattobase: The Linguistic Structure of Japanese Baseball Chants
}

\author{
Junko Ito $^{1,2}$, Haruo Kubozono ${ }^{2}$, Armin Mester $^{1,2}$, and Shin'ichi Tanaka ${ }^{3}$ \\ ${ }^{1}$ UC Santa Cruz, ${ }^{2}$ NINJAL (Tokyo, Japan), ${ }^{3}$ Kobe University (Japan)
}

\section{Introduction}

This paper develops the first constraint-based analysis of Japanese baseball chants, whose intricate organization casts a very revealing sidelight on the prosodic organization of the Japanese language itself. The source of most data and basic generalizations is the last author's dissertation (Tanaka 2008), supplemented by further empirical probing which clarified a number of unclear points.

Since the beginnings of metrical phonology, the analysis of chants has played an important role in the development of the theory. Liberman (1975) uses the English vocative chant ("Jo-ohn!", with a High-Mid tune) to motivate basic properties of what came to be known as the "metrical theory of stress". He shows that, in order to formalize tune-to-text alignment, and to define what it means for a tune to be congruent with a text and its metrical pattern, a relational understanding of stress is necessary, as instantiated in metrical trees with their "strong-weak" labeling of all nodes.

Japanese baseball chants, an obligatory and quasi-ritual part of virtually every baseball game, are delivered by fans each time their team is at bat. They are accompanied by a variety of musical instruments (drums, trumpets, etc.) and take the form in (1). They consist of two measures of four beats, each composed of three notes plus one pause. 'XXX' is a rhythmically adapted form of the player's name. At issue here is the form of the rhythmic adaptation, which is tightly regulated and grounded, as we will show, in the rhythmic structure of the language itself.

(1)

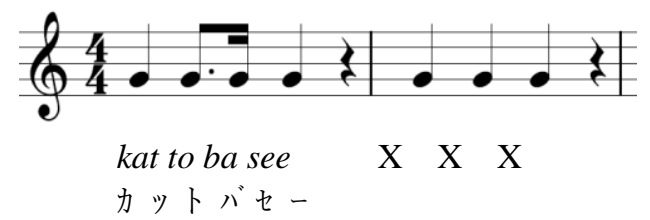

Morphological structure:

kat- tob - as -e

INTENSIFIER-fly-CAUS-IMP

'send it flying, hit a homerun'

The examples in (2) illustrate the phenomenon. ${ }^{1}$

\footnotetext{
${ }^{*}$ For helpful comments, we are thankful to audiences at Grinnell College, Waseda University, UC Santa Cruz, and UC San Diego. We are particularly indebted to Adam Albright, Eric Baković, Ryan Bennett, Edward Flemming, Chris Golston, Bruce Hayes, and Angelo Mercado. Special thanks to Nick Kalivoda for extensive and very helpful comments on an earlier version.

${ }^{1}$ Our transcription is approximately phonemic and largely follows the Hepburn style of Romanization used by the leading dictionaries (Kenkyusha, among others), with some minor modifications: Vowel length is denoted by doubling; $\mathrm{chi}=\widetilde{[\mathrm{t} i}], \mathrm{tsu}=[\widehat{\mathrm{tsu}}], \mathrm{shi}=[\mathrm{fi}], \mathrm{ji}=[\widehat{\mathrm{d}} \mathrm{i} \mathrm{i}], \mathrm{hi}=[\mathrm{ci}], \mathrm{fu}=[\phi \mathrm{u}]$; and $\mathrm{n}$ stands for the moraic nasal of Japanese, realized as a nasal glide (assimilating in place to following stop consonants).
} 


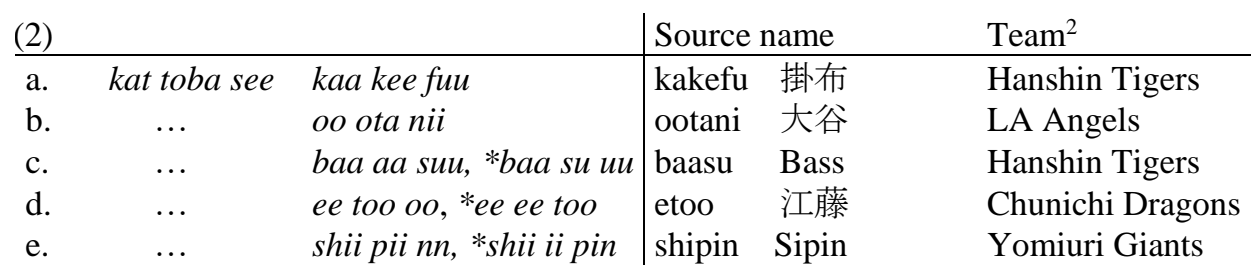

By way of introduction, we first summarize Tanaka's (2008) analysis, and at the same time present relevant examples. There are three separate rules, depending on the length of the input name, measured in moras $(\mu)$. Each CV- or V-unit is one mora, so ichiroo $=i$-chi-ro-o is a $4 \mu$ name. Syllable-final consonants (mostly nasals) are also one mora (son $=s o-n=2 \mu)$.

Rule 1 in (3) deals with names up to $3 \mu$. The simplest case is names of exactly $3 \mu$, which fit the $X_{1} X_{2} X_{3}$ template exactly, as seen in (4) (we write "L" for "light syllable", "H" for "heavy syllable", and "S" for "superheavy syllable").

(3) Rule 1a 3-mora names: Align the initial mora to the initial beat $\left(\mathrm{X}_{1}\right)$, the final mora to the final beat $\left(\mathrm{X}_{3}\right)$, the medial mora to the medial beat $\left(\mathrm{X}_{2}\right)$.

\begin{tabular}{l|r|lll|l} 
Moras & Profile & \multicolumn{2}{|c|}{ Input } & Output \\
\hline \multirow{3}{*}{3} & LLL & a. & ka-ke-fu & 掛布 & kaa-kee-fuu \\
\cline { 2 - 5 } & HL & b. & ba-a-su & Bass & baa-aa-suu \\
\cline { 2 - 5 } & & c. & ge-n-da & 源田 & gee-nn-daa \\
\cline { 2 - 5 } & d. & sa-i-ki & 才木 & saa-ii-kii \\
\cline { 2 - 5 } & LH & e. & e-to-o & 江藤 & ee-too-oo
\end{tabular}

It is important that the final mora goes to $\mathrm{X}_{3}$, not the final syllable: This is why $\mathrm{LH}\left[e_{1}\right]-\left[t_{2}-o_{3}\right] \rightarrow\left[e_{1}-e\right]-$ $\left[t o_{2}-o\right]-\left[o_{3}-o\right]$ and not $*\left[e_{1}-e\right]-[e-e]-\left[t o_{2} o_{3}\right]$. By the same rule, HL $\left[b a_{1}-a_{2}\right]-\left[s u_{3}\right] \rightarrow\left[b a_{1}-a\right]-\left[a_{2}-a\right]-\left[s u_{3}-u\right]$, not $*\left[b a_{1}-a_{2}\right]-\left[s u_{3}-u\right]-[u-u]$.

Rule $1 \mathrm{~b}$ in (5) deals with shorter names. The crucial point is that the first mora fills $\mathrm{X}_{1}$ and $\mathrm{X}_{2}\left(\mathrm{ta}_{1^{-}}\right.$ $\left.n i_{2} \rightarrow t a_{1} a-a a-n i_{2} i\right)$, not the second mora $\mathrm{X}_{2}$ and $\mathrm{X}_{3}\left({ }^{*} t a_{1} a-n i_{2} i-i i\right)$.

(5) Rule $1 \mathrm{~b} \quad$ In $2 \mu$ names, there is no medial mora. Spread from the left to fill $X_{2}$. In $1 \mu$ names, there is only an initial mora. Spread from the left to fill $X_{2}$ and $X_{3}$.

Illustrative examples appear in (6).

\begin{tabular}{l|r|lll|l} 
Moras & Profile & \multicolumn{3}{|c|}{ Input } & Output \\
\hline 2 & LL & a. & tani & 谷 & taa-aa-nii \\
\cline { 2 - 5 } & & b. & yano & 矢野 & yaa-aa-noo \\
\cline { 2 - 5 } & H & c. & son & 宣 & soo-oo-nn \\
\cline { 3 - 5 } & & d. & chen & 陳 & chee-ee-nn \\
\cline { 3 - 5 } & & e. & rii & Lee & rii-ii-ii \\
\cline { 2 - 5 } & f. & kai & 甲斐 & ka-aa-ii \\
\hline 1 & L & g. & ri & 李 & rii-ii-ii
\end{tabular}

(6cd) again illustrate the final-mora rule: $n$ alone fills $\mathrm{X}_{3}$, not the final rhyme on: $\left[\right.$ so $\left._{1}-n_{2}\right] \rightarrow$ $\left[\mathrm{so}_{1}-\mathrm{o}\right]-[o-o]-\left[n_{2}-n\right]$, not $*\left[\mathrm{so}_{1}-\mathrm{o}\right]-[o-o]-\left[o-n_{2}\right]$.

Things are different with $4 \mu$ names, and longer names: Now the whole final syllable goes to $X_{3}$, whether light or heavy: $\left[i_{1}\right]-\left[\mathrm{Chi}_{2}\right]-\left[\mathrm{ro}_{3}-\mathrm{O}_{4}\right] \rightarrow\left[i_{1} i\right]-\left[\mathrm{Chi}_{2} i\right]-\left[\mathrm{ro}_{3}-\mathrm{O}_{4}\right](8 \mathrm{e})$, and not the final mora $\left(*\left[i_{1} i\right]-\left[\mathrm{Chi}_{2} \mathrm{ro}_{3}\right]-\left[\mathrm{o}_{4}-\mathrm{o}\right]\right.$. A new rule is therefore needed, given in (7).

\footnotetext{
${ }^{2}$ See the Appendix for an alphabetized list of source names and player affiliation.
} 
Rule 2 4-mora names: Align the initial mora to $\mathrm{X}_{1}$, the final syllable to $\mathrm{X}_{3}$, medial moras to $\mathrm{X}_{2}$.

More examples illustrating the pattern are given in (8).

\begin{tabular}{l|r|lll|l} 
Moras & Profile & \multicolumn{3}{|c|}{ Input } & Output \\
\hline 4 & LLLL & a. & kiyohara & 清原 & kii-yoha-raa \\
\cline { 3 - 5 } & & b. & tatsunami & 立浪 & taa-tsuna-mii \\
\hline & c. & rinaresu & Linares & rii-nare-suu \\
\hline & d. & kuromati & Cromartie & kuu-roma-tii \\
\hline \multirow{5}{*}{ LLH } & e. & ichiroo & イチロ & ii-chii-roo \\
\hline & f. & ochiai & 落合 & oo-chii-ai \\
\hline & g. & wiruson & Wilson & wii-ruu-son \\
\hline \multirow{2}{*}{ HLL } & h. & joojima & 城島 & joo-oji-maa \\
\hline & i. & ootomo & 大友 & oo-oto-moo \\
\hline \multirow{2}{*}{ HH } & j. & hansen & Hansen & haa-nn-sen \\
\hline & k. & taihoo & 大豊 & taa-ii-hoo \\
\hline & l. & shinjoo & 新庄 & shii-nn-joo \\
\hline \multirow{2}{*}{ LHL } & m. & furanko & Franco & fuu-ran-koo
\end{tabular}

Besides the emergence of the final syllable as a mapping target, the mapping of HLL names (8hi) is remarkable: $\left[j o_{1}-o_{2}\right]-\left[j i_{3}\right]-\left[\mathrm{ma}_{4}\right] \rightarrow\left[j o_{1} o\right]-\left[o_{2}-j i_{3}\right]-\left[m a_{4} a\right]$, not $*\left[j o_{1}-o_{2}\right]-\left[j i_{3} i\right]-\left[m a_{4} a\right]$. As indicated, we understand the winning output as mapping the two $o$-moras to different beats (with an onset violation). Here we simply note the facts, and will return to their explanation in the next section.

A special case are $4 \mu$ names like $\left[k u_{1}\right]-\left[\mathrm{ra}_{2}-i_{3}-n_{4}\right]$ (Klein) $(9 \mathrm{a})$, whose profile seems to be LS. If it is the case that the superheavy syllable is actually broken up into $\mathrm{L}+\mathrm{H}\left[k u_{1}\right]-\left[\mathrm{ra}_{2}\right]-\left[i_{3}-n_{4}\right]$, as argued by several authors, including Vance (2008, 125-127), Kubozono (2015, 13-16), and Ito and Mester (2018, 212-216), the final syllable rule already covers this case. The long vowel in (9b) seems to resist this kind of splitting.

\begin{tabular}{l|l|lll|l} 
Moras & Profile & \multicolumn{3}{|c|}{ Input } & Output \\
\hline 4 & \multirow{2}{*}{ LS or LLH } & a. & kurain & Klein & kuu-raa-in ${ }^{3}$ \\
\cline { 3 - 5 } & & b. & kuruun & Kroon & kuu-ruu-nn \\
\cline { 2 - 5 } & SL or LHL & c. & baanzu & Barnes & baa-an-zuu \\
\hline & d. & joonzu & Jones & joo-on-zuu
\end{tabular}

Names with 5 or more moras follow the same final syllable rule, but we need to distinguish two cases on the basis of the weight of the penultimate syllable. Names with penultimate $\mathrm{H}$ map this syllable to $\mathrm{X}_{2}$, as formulated in (10) and illustrated in (11).

(10) Rule $3 a \quad \geq 5 \mu$ names with $H$ penultimate syllable: Align the final syllable to $X_{3}$, the penultimate $\mathrm{H}$ syllable to $\mathrm{X}_{2}$, the remainder (which can be of any length) to $\mathrm{X}_{1}$.

\begin{tabular}{l|r|lll|l} 
Moras & Profile & \multicolumn{2}{|c|}{ Input } & Output \\
\hline \multirow{2}{*}{5} & HHL & a. & boochaado & Borchard & boo-chaa-doo \\
\cline { 2 - 5 } & LLHL & b. & seginooru & Seguignol & segi-noo-ruu \\
\cline { 2 - 5 } & LHH & c. & deshinsei & DeCinces & dee-shin-sei \\
\hline 6 & LLLHL & d. & desutoraade & Destrade & desuto-raa-dee
\end{tabular}

In (12) we give the corresponding rule for names with $\mathrm{L}$ in the penult, as illustrated in (13).

\footnotetext{
3 Another less preferred variant is kuu-rai-nn.
} 
(12) Rule 3b

$\geq 5 \mu$ names with $L$ penultimate syllable: Align the final syllable to $X_{3}$, the penultimate $\mathrm{L}$ syllable and the antepenultimate syllable (whether $\mathrm{L}$ or $\mathrm{H}$ ) to $\mathrm{X}_{2}$, the remainder (which can be of any length) to $\mathrm{X}_{1}$.

(13)

\begin{tabular}{l|r|lll|l} 
Moras & Profile & \multicolumn{2}{|c|}{ Input } & Output \\
\hline 5 & HLLL & a. & gonzaresu & González & gon-zare-suu \\
\hline 6 & LLLLLL & b. & makudonarudo & Macdonald & makudo-naru-doo \\
\cline { 2 - 5 } & LHLH & c. & robaatoson & Robertson & roo-baato-son
\end{tabular}

In (14), we give more examples of $\geq 5 \mu$ names.

\begin{tabular}{|c|c|c|c|c|c|}
\hline Moras & Profile & & Input & & Output \\
\hline \multirow[t]{12}{*}{5} & LLLLL & a. & ogasawara & 小笠原 & oga-sawa-raa \\
\hline & LLLLL & b. & kobayakawa & 小早川 & koba-yaka-waa \\
\hline & LHLL & c. & arekkusu & Alex & aa-rekku-suu \\
\hline & LHLL & d. & mahoomuzu & Mahomes & maa-hoomu-zuu \\
\hline & LLHL & e. & kitabeppu & 北別府 & kita-bep-puu \\
\hline & LLLH & f. & oguribii & Oglivie & oo-guri-bii \\
\hline & HHL & g. & infante & Infante & in-fan-tee \\
\hline & HHL & h. & boochaado & Borchard & boo-chaa-doo \\
\hline & $\mathrm{LHH}$ & i. & buranboo & Brumbaugh & buu-ran-boo \\
\hline & HLH & j. & oosutin & Austin & oo-osu-tin \\
\hline & $\mathrm{HLH}$ & $\mathrm{k}$. & doddoson & Dodson & doo-oddo-son \\
\hline & HLH & 1. & bansuroo & Vance Law & baa-nsu-roo \\
\hline \multirow[t]{5}{*}{6} & HLLLL & $\mathrm{m}$. & kontorerasu & Contreras & konto-rera-suu \\
\hline & LHLLL & $\mathrm{n}$. & furanshisuko & Francisco & furan-shisu-koo \\
\hline & LLHLL & o. & ferunandesu & Fernández & feru-nande-suu \\
\hline & LLLHL & p. & desutefaano & Distefano & desute-faa-noo \\
\hline & LLLLH & q. & makanarutii & McAnulty & maka-naru-tii \\
\hline 7 & HLHLL & r. & gengoroomar & 源五郎丸 & gengo-rooma-ruu \\
\hline
\end{tabular}

\section{Analysis}

The challenge any analysis must cope with is that we seem to be dealing with three separate patterns, as summarized in (15).

1. for $\leq 3$-mora names: last mora goes to last beat

2. for 4-mora names: last syllable goes to last beat

3. for $\geq 5$-mora names: last syllable goes to last beat, and special provisos for $\mathrm{H}$ and $\mathrm{L}$ penults

Ideally we would like to unify everything into a single rule, but the distinction between the three patterns seems very well motivated, having to do with the length of the input. Since the overall goal is to split the input into three parts, which are then mapped to the three beats, it makes sense that what goes into the last beat is different for short names and for longer names. But "making sense" is not yet an explanation-our goal is now to give an analysis in Optimality Theory (OT, Prince and Smolensky 1993), in terms of ranked and violable constraints, and capture the different aspects of the pattern in one single and uniform constraint ranking, instead of having three distinct procedures.

We first lay out our constraints, beginning in (16), where "K" stands for "kattobase form". 
(16)
a. $\mathrm{K}=\mathrm{X}_{1} \mathrm{X}_{2} \mathrm{X}_{3}$
A kattobase form consists of 3 beats, $\mathrm{X}_{1} \mathrm{X}_{2} \mathrm{X}_{3}$.
b. $\mathrm{X} \geq$ FOOT
A beat is minimally a foot $(\mathrm{Ft})$.
c. $\operatorname{FOOTFORM}\left(\mathrm{X}_{2}\right) \quad \mathrm{X}_{2}$ is a quantitative trochee (H, LL, or HL).
d. MAX $\quad$ Every element of the input is present in $\mathrm{K}$.
e. Align-LEFT $\left.\left(\mathrm{X}_{3}, \mu\right]\right) \quad$ The left edge of $\mathrm{X}_{3}$ corresponds to the left edge of (the content of) the last mora of the input. One violation when the edges do not coincide.
f. Align-LEFT $\left.\left(\mathrm{X}_{3}, \sigma\right]\right) \quad$ The left edge of $\mathrm{X}_{3}$ corresponds to the left edge of (the content of) the last syllable of the input. One violation when the edges do not coincide.

For our purposes, the basic rhythmic structure of Japanese is the trochaic (strong-weak, sw) foot with the three forms in (17), which include the uneven trochee HL, for reasons we will return to.

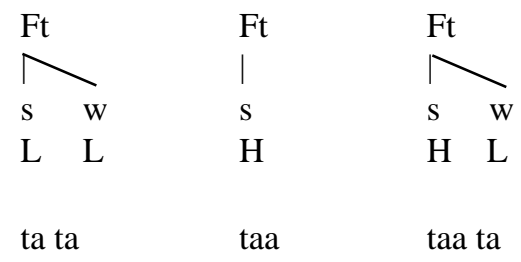

(16c) raises an immediate question: Why is there a special constraint requiring $\mathrm{X}_{2}$ to be exactly a trochee? Empirically speaking, the answer is clear: In long names, material exceeding the size of a trochee goes into $\mathrm{X}_{1}$, not into $\mathrm{X}_{2}$ : MacDonald $\rightarrow$ makudo-naru-doo, not *maku-donaru-doo. $\mathrm{X}_{3}$ is in any case restricted to the last syllable of the input because of the Align-LEFT constraints $(\sigma, \mu)$ : MacDonald $\rightarrow$ makudo-naru-doo, *maku-dona-rudo.

But what is the reason $\mathrm{X}_{2}$ plays this special role, not $\mathrm{X}_{1}$ or $\mathrm{X}_{3}$ ? Our hypothesis is that the reason lies in what $\mathrm{X}_{2}$ corresponds to in a Japanese word: It corresponds to the last, and most prominent, foot of the word, the foot which receives the default antepenultimate accent, as illustrated in (18).

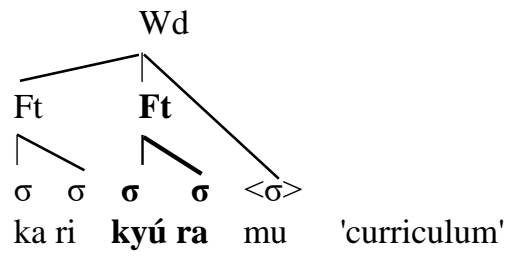

If so, FoOTFORM $\left(\mathrm{X}_{2}\right)$ is actually FoOTFORM(HEADFOOT), a positional markedness constraint, as in (19).

FoOTFORM(HDFT) The headfoot is a quantitative trochee (H, LL, or HL).

In conjunction with (20a), the general DEP- $\mu$ constraint militating against any kind of lengthening, there is also another headfoot-specific positional faithfulness constraint (20b) preventing epenthesis in $\mathrm{X}_{2}$.
a. DEP- $\mu$
Every mora in the output has a correspondent in the input — no epenthesis of a mora (i.e., no lengthening).
b. DEP- $\mu$ Every mora in the output's head foot has a correspondent in the input-no (HDFT) epenthesis of a mora (i.e., no lengthening).

The remaining constraints cover familiar territory: There are two crisp edge constraints (Ito and Mester 1999) militating against spreading consonants or vowels across X-boundaries (21ab), and the familiar onset constraint (21c). 
(21)

\begin{tabular}{l|l} 
a. CRISPEDGE-C & $\begin{array}{l}\text { The edges of } \mathrm{X} \text { are crisp: no spreading of consonants across. One violation } \\
\text { for every consonant linked to two different Xs. }\end{array}$ \\
\hline b. CRISPEDGE-V & $\begin{array}{l}\text { The edges of } \mathrm{X} \text { are crisp: no spreading of vowels across. One violation for } \\
\text { every vowel linked to two different Xs. }\end{array}$ \\
\hline c. ONSET & A syllable has an onset.
\end{tabular}

The overall ranking of the constraints is as in (22). We will gradually justify all dominance relations.

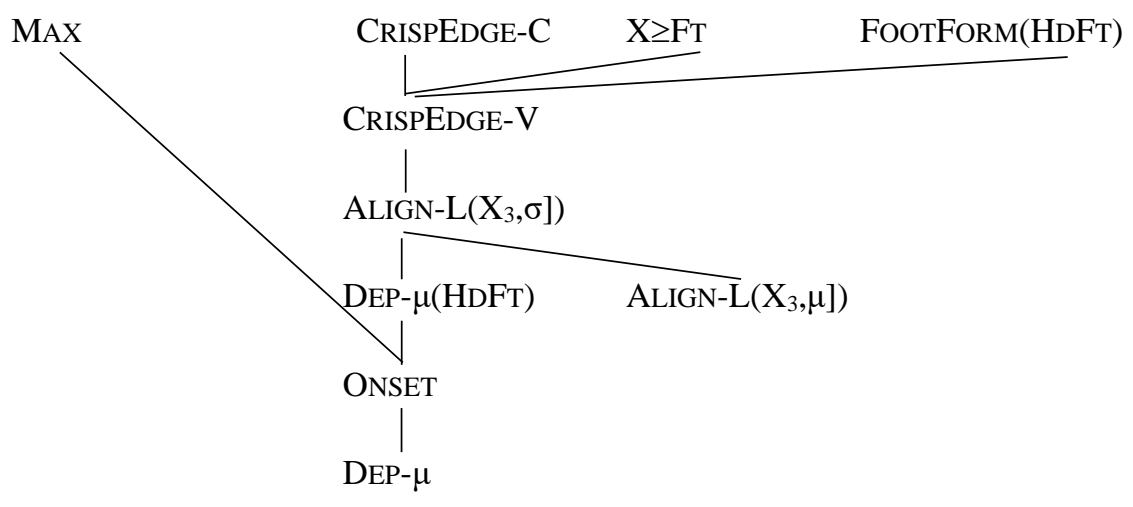

The simplest case is $3 \mu$ names (23) such as $k a_{1}-k e_{2}-f u_{3} \rightarrow k a_{1} a-k e_{2} e-f u_{3} u$. Comparing the winning candidate (23a) with (23d) $* k a_{1} a-k e_{2} f u_{3}-u u$, we see the constraint DEP- $\mu(\mathrm{HDFT})$, violated by the winner, must be dominated by either CRISPEDGE-V or ALIGN-L $\left(\mathrm{X}_{3}, \sigma\right)$, which are both violated by the loser. ${ }^{4}$

\begin{tabular}{|c|c|c|c|c|c|c|c|c|c|c|c|}
\hline INPUT & OUTPUT & $\mid \begin{array}{l}3 \\
3\end{array}$ & $\begin{array}{l}\Omega \\
\widetilde{\Omega} \\
\bar{\Omega} \\
\bar{T} \\
1 \\
\Omega\end{array}$ & $\begin{array}{l}\underset{X}{\mathrm{~V}} \\
\mathrm{~T} \\
\rightarrow\end{array}$ &  & $\begin{array}{l}\Omega \\
\pi \\
\sqrt{2} \\
\bar{\pi} \\
1 \\
<\end{array}$ & 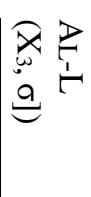 & 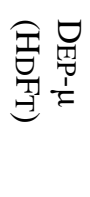 & 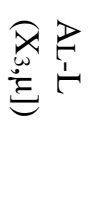 & $\left|\begin{array}{l}0 \\
Z \\
\text { Z } \\
\text { 崶 }\end{array}\right|$ & $\mid \begin{array}{c}\nabla \\
\frac{\pi}{0} \\
\frac{1}{2}\end{array}$ \\
\hline \multirow{7}{*}{$\begin{array}{l}\text { kakefu } \\
\text { 掛布 }\end{array}$} & a. kaa-kee-fuu & & & & & & & 1 & & & 3 \\
\hline & b. kaa-ake-fuu & & & & & 1 & & 1 & & 1 & 3 \\
\hline & $\begin{array}{ll}\text { c. } & \text { kake-ee-fuu } \\
\end{array}$ & & & & & 1 & & 2 & & 1 & 3 \\
\hline & kaa-kefu-uu & & & & & 1 & 1 & & 1 & 1 & 3 \\
\hline & kake-fuu-uu & & & & & 1 & 1 & 1 & 1 & 1 & 3 \\
\hline & kaa-aa-kefu & & & & & 1 & 1 & 2 & 1 & 1 & 3 \\
\hline & g. $\quad$ ka-ke-fu & & & 3 & 1 & & & & & & \\
\hline
\end{tabular}

The winning candidate kaa-kee-fuu also shows three instances of mora epenthesis, and thus violates general DEP- $\mu$ three times. Since this constraint is bottom-ranked and does not contribute to the explanation in interesting ways, we will in general not include it in our tableaux.

Turning next to short names, we give tableaux for $1 \mu$ - and $2 \mu$-names in (24) and (25).

4 Technically, ONSET or AL-L $\left.\left(X_{3}, \mu\right]\right)$ could also dominate DEP- $\mu(\mathrm{HDFT})$ with the same effect, but we will soon see that these must be ranked lower. 


\begin{tabular}{|c|c|c|c|c|c|c|c|c|c|c|c|}
\hline INPUT & & OUTPUT & $\frac{3}{x}$ & 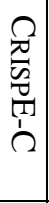 & $\begin{array}{l}\underset{x}{\mathrm{~V}} \\
\mathrm{I} \\
\rightarrow\end{array}$ & 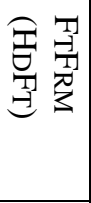 & 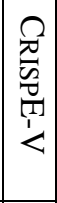 & 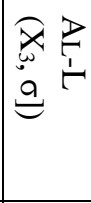 & 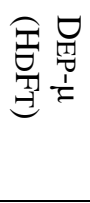 & 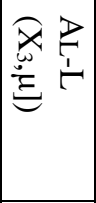 & 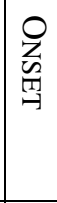 \\
\hline ri & a. & - rii-ii-ii & & & & & 2 & 1 & 2 & 1 & 2 \\
\hline \multirow[t]{6}{*}{ 李 } & b. & ii-ii-ii & 1 & & & & 2 & 1 & 2 & 1 & 3 \\
\hline & c. & rii-X-ii & & & 1 & & 1 & 1 & & 1 & 1 \\
\hline & d. & X-X-rii & & & 2 & & & & & & \\
\hline & e. & ri-X-X & & & 3 & & & & & & \\
\hline & f. & X-X-ri & & & 3 & & & & & & \\
\hline & g. & ri-i-i & & & 3 & 1 & 2 & 1 & 1 & 1 & 2 \\
\hline
\end{tabular}

The fact that (24a) wins over (24def) shows that $\mathrm{X} \geq \mathrm{FT}$ dominates all of CRISPE-V, AL-L(X $\left.\left.\mathrm{X}_{3}, \sigma\right]\right)$, DEP$\left.\mu(\mathrm{HDFT}), \mathrm{AL}-\mathrm{L}\left(\mathrm{X}_{3}, \mu\right]\right)$, and ONSET. In (25), (25a) $t a_{1} a-a a-n i_{2} i$, with its two violations of DEP- $\mu(\mathrm{HDFT})$, wins over (25b) $t a_{1} a-n i_{2} i-i i$ (with only one violation). This teaches us that AL-L(X $\left.\left.\mathrm{X}_{3}, \sigma\right]\right)>>\mathrm{DEP}-\mu(\mathrm{HDFT})$ (the loser does not align the last syllable with $\left.\mathrm{X}_{3}\right) .{ }^{5}$ Another possibility would be AL-L $\left.\left(\mathrm{X}_{3}, \mu\right]\right)>>$ DEP- $\mu(\mathrm{HDFT})$, but we will see below in (32) that there is independent evidence for AL-L(X $\left.\left.\mathrm{X}_{3}, \sigma\right]\right)>>\mathrm{DEP}-\mu(\mathrm{HDFT})$.

\begin{tabular}{|c|c|c|c|c|c|c|c|c|c|c|}
\hline INPUT & OUTPUT & $\begin{array}{l}3 \\
x \\
x\end{array}$ & 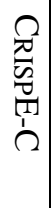 & $\begin{array}{l}x \\
\mathrm{~V} \\
\mathrm{I} \\
-1\end{array}$ & 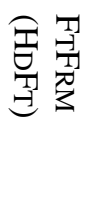 & $\begin{array}{l}\Omega \\
\frac{\pi}{\tilde{n}} \\
0 \\
1 \\
1 \\
<\end{array}$ & $\begin{array}{ll}x & p \\
w & 1 \\
a & -1\end{array}$ &  & 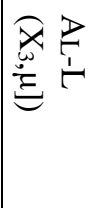 & $\begin{array}{l}0 \\
Z \\
\text { 感 } \\
\end{array}$ \\
\hline $\operatorname{tani}$ & a. taa-aa-nii & & & & & 1 & & 2 & & 1 \\
\hline \multirow[t]{3}{*}{ 谷 } & b. taa-nii-ii & & & & & 1 & 1 & 1 & 1 & 1 \\
\hline & c. $\quad$ tani-ii-ii & & & & & 2 & 1 & 2 & 1 & 2 \\
\hline & d. nii-ii-ii & 2 & & & & 2 & 1 & 2 & 1 & 1 \\
\hline
\end{tabular}

(26a) so1o-oo- $n_{2} n$ beats, and harmonically bounds, (26b) solo-oo-on2 because it does better on CRISPE-V and $\operatorname{AL}-\mathrm{L}\left(\mathrm{X}_{3}, \mu\right)$.

\begin{tabular}{|c|c|c|c|c|c|c|c|c|c|c|}
\hline INPUT & OUTPUT & $\mid \frac{3}{x}$ & $\left|\begin{array}{c}\Omega \\
\widetilde{0} \\
\tilde{2} \\
\frac{1}{1} \\
\Omega\end{array}\right|$ & $\left|\begin{array}{l}x \\
\mathbb{V} \\
\mathbb{T} \\
-1\end{array}\right|$ & 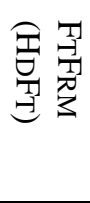 & 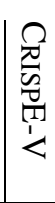 & $\mid \begin{array}{ll}x & D \\
w & 1 \\
a & -\end{array}$ & 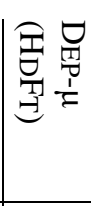 & 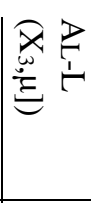 & $\mid \begin{array}{l}0 \\
Z \\
\text { Z } \\
\text { 出 }\end{array}$ \\
\hline son & a. soo-oo-nn & & & & & 1 & 1 & 2 & & 2 \\
\hline 宣 & b. soo-oo-on & & & & & 2 & 1 & 2 & 1 & 2 \\
\hline & c. soo-nn-nn & & 1 & & & & 1 & 1 & 1 & 2 \\
\hline & d. son-nn-nn & & 2 & & & & 1 & 2 & 1 & 2 \\
\hline
\end{tabular}

A similar point holds for $b a_{1} a_{2} s u_{3} \rightarrow b a_{1} a-a_{2} a-s u_{3} u$ and $g e_{1} n_{2} d a_{3} \rightarrow g e_{1} e-n_{2} n-d a_{3} a$ in (27). Note that the winning candidate $b a_{1} a-a_{2} a-s u_{3} u$ assigns the two $a$-moras to different syllables - the candidate $b a_{1} a_{2}$ - $a a_{-}-s u_{3} u$ does worse both on CRISPE-V, AL-L $(X 3, \sigma)$ and DEP- $\mu(\mathrm{HDFT})$ and is harmonically bounded by the winner.

\footnotetext{
5 Another possibility would be AL-L $\left.\left(\mathrm{X}_{3}, \mu\right]\right)>>\mathrm{DEP}-\mu(\mathrm{HDFT})$, but we will see below in (32) that there is independent evidence for $\left.\mathrm{AL}-\mathrm{L}\left(\mathrm{X}_{3}, \sigma\right]\right)>>\mathrm{DEP}-\mu(\mathrm{HDFT})$.
} 


\begin{tabular}{|c|c|c|c|c|c|c|c|c|c|c|}
\hline INPUT & OUTPUT & $\left|\begin{array}{l}3 \\
x\end{array}\right|$ & 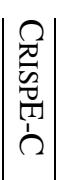 & 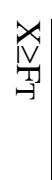 & 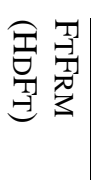 & $\mid \begin{array}{c}0 \\
0 \\
\overline{2} \\
0 \\
11 \\
1 \\
<\end{array}$ & $\mid \begin{array}{ll}x & \geq \\
0 & 1 \\
\underbrace{a} & -\end{array}$ & 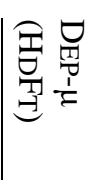 & 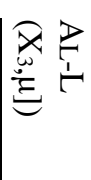 & $\mid \begin{array}{l}0 \\
Z \\
\text { Z } \\
\text { 夏 }\end{array}$ \\
\hline $\mathrm{ba}_{1} \mathrm{a}_{2} \mathrm{su}_{3}$ & a. $\mathrm{ba}_{1} \mathrm{a}-\mathrm{a}_{2} \mathrm{a}-\mathrm{su}_{3} \mathrm{u}$ & & & & & & & 1 & & 1 \\
\hline \multirow[t]{4}{*}{ Bass } & b. $\quad$ ba $_{1} a_{2}-\mathrm{su}_{3} \mathrm{u}-\mathrm{uu}$ & & & & & 1 & 1 & 1 & 1 & 1 \\
\hline & c. $\quad \mathrm{ba}_{1} \mathrm{a}_{2}-\mathrm{aa}-\mathrm{su}_{3} \mathrm{u}$ & & & & & 1 & & 2 & 1 & 1 \\
\hline & d. $\quad$ ba $_{1} a-a_{2} s_{3}-u u$ & & & & & 1 & 1 & & 1 & 2 \\
\hline & e. $\quad X-b_{1} a_{2}-s_{3} u$ & & & 1 & & & & & & \\
\hline $\mathrm{ge}_{1} \mathrm{n}_{2} \mathrm{da}_{3}$ & f. $\longrightarrow \mathrm{ge}_{1} \mathrm{e}-\mathrm{n}_{2} \mathrm{n}-\mathrm{da}_{3} \mathrm{a}$ & & & & & & & 1 & & 1 \\
\hline \multirow[t]{2}{*}{ 源田 } & g. $\quad$ ge $_{1} n_{2}-$ daa-a $a$ & & & & & 1 & 1 & 1 & 1 & 1 \\
\hline & h. $\quad$ ge $_{1} n_{2}-$ nn-da $_{3} a$ & & 1 & & & & & 1 & & 1 \\
\hline
\end{tabular}

An interesting contrast to the HL-word $b a_{1} a_{2} s u_{3} \rightarrow b a_{1} a-a_{2} a-s u_{3} u$ is the LH word $e_{1} t_{2} O_{3} \rightarrow e_{1} e-t o_{2} O-o_{3} O$ in (28): Even though Align-Left $\left.\left(\mathrm{X}_{3}, \sigma\right]\right)$, which ranks higher than $\left.\operatorname{AligN-LEFT}\left(\mathrm{X}_{3}, \mu\right]\right)$, favors (28b), CRISPEDGE-V, which ranks even higher, selects (28a).

\begin{tabular}{|c|c|c|c|c|c|c|c|c|c|c|}
\hline INPUT & OUTPUT & $\mid \begin{array}{l}3 \\
x\end{array}$ & \begin{tabular}{c}
$\Omega$ \\
\multicolumn{2}{c}{} \\
$\overline{2}$ \\
$\overline{1}$ \\
1 \\
$\Omega$
\end{tabular} & $\mid \begin{array}{l}x \\
\text { IV } \\
-1 \\
-1\end{array}$ & 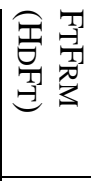 & $\mid \begin{array}{l}0 \\
2 \\
0 \\
0 \\
0 \\
1 \\
<\end{array}$ & $\mid \begin{array}{ll}x & D \\
w & 1 \\
a & -\end{array}$ & 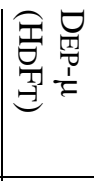 & $\mid \begin{array}{ll}\not{x} & D \\
0 & 1 \\
\stackrel{E}{E} & -1\end{array}$ & 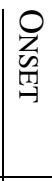 \\
\hline \multirow{3}{*}{$\begin{array}{l}\mathrm{e}_{1} \mathrm{to}_{2} \mathrm{O}_{3} \\
\text { 江藤 }\end{array}$} & a. $\mathrm{e}_{1} \mathrm{e}-\mathrm{to}_{2} \mathrm{O}-\mathrm{O}_{3} \mathrm{O}^{6}$ & & & & & & 1 & 1 & & 2 \\
\hline & b. $\quad \mathrm{e}_{1} \mathrm{e}-\mathrm{ee}-\mathrm{to}_{2} \mathrm{O}_{3}$ & & & & & 1 & & 2 & 1 & 2 \\
\hline & c. $\mathrm{e}_{1} \mathrm{to}_{2}-\mathrm{O}_{3} \mathrm{O}-\mathrm{OO}$ & & & & & 1 & $\mid 1$ & 1 & & 2 \\
\hline
\end{tabular}

To recapitulate the crucial constraint interactions, we compare the derivations for tani, baasu, and etoo in (29).

\begin{tabular}{|c|c|c|c|c|}
\hline INPUT & OUTPUT & 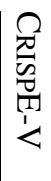 & $\mid \begin{array}{ll}\underset{x}{x} & 2 \\
0 & 1 \\
a & -1\end{array}$ & 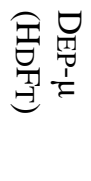 \\
\hline \multirow{2}{*}{$\begin{array}{c}\mathrm{LL} \operatorname{ta}_{1} \mathrm{ni}_{2} \\
\text { 谷 } \\
\end{array}$} & a. $>$ ta $_{1}$ a-aa-ni $i_{2} \mathrm{i}$ & 1 & & 2 \\
\hline & b. $\quad$ ta $_{1} \mathrm{a}-\mathrm{ni}_{2} \mathrm{i}-\mathrm{ii}$ & 1 & 1 & 1 \\
\hline 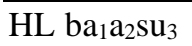 & c. $\mathrm{ba}_{1} \mathrm{a}-\mathrm{a}_{2} \mathrm{a}-\mathrm{su}_{3} \mathrm{u}$ & & & 1 \\
\hline Bass & d. $\quad b_{1} a-a_{2} s u_{3}-u u$ & 1 & 1 & \\
\hline \multirow{2}{*}{$\begin{array}{c}\mathrm{LH} \mathrm{e}_{2} \mathrm{to}_{2} \mathrm{O}_{3} \\
\text { 江藤 }\end{array}$} & e. $\quad \mathrm{e}_{1} \mathrm{e}-\mathrm{ee}-\mathrm{to}_{2} \mathrm{O}_{3}$ & 1 & & 2 \\
\hline & f. $-\mathrm{e}_{1} \mathrm{e}-\mathrm{to}_{2} \mathrm{O}-\mathrm{O}_{3} \mathrm{O}$ & & 1 & 1 \\
\hline
\end{tabular}

While in $3 \mu$-words ending in $\mathrm{H}$ the last mora, not the last syllable, is assigned to $\mathrm{X}_{3}$ (because of CrispE-V, see (29ef)), this is not the case in $4 \mu$-words ending in $\mathrm{H}$, as shown in (30). Here (30a) and (30e) do not violate CrispE-V, so $\left.\mathrm{AL}-\mathrm{L}\left(\mathrm{X}_{3}, \sigma\right]\right)$ decided in favor of the candidates assigning the final syllable to $\mathrm{X}_{3}$.

\footnotetext{
${ }^{6}$ Note that the two parts of the long vowel are evaluated separately by CRISPE-V, that is why the winner $e_{1} e-t_{2} o_{2}-O_{3} O$ does not violate this constraint.
} 


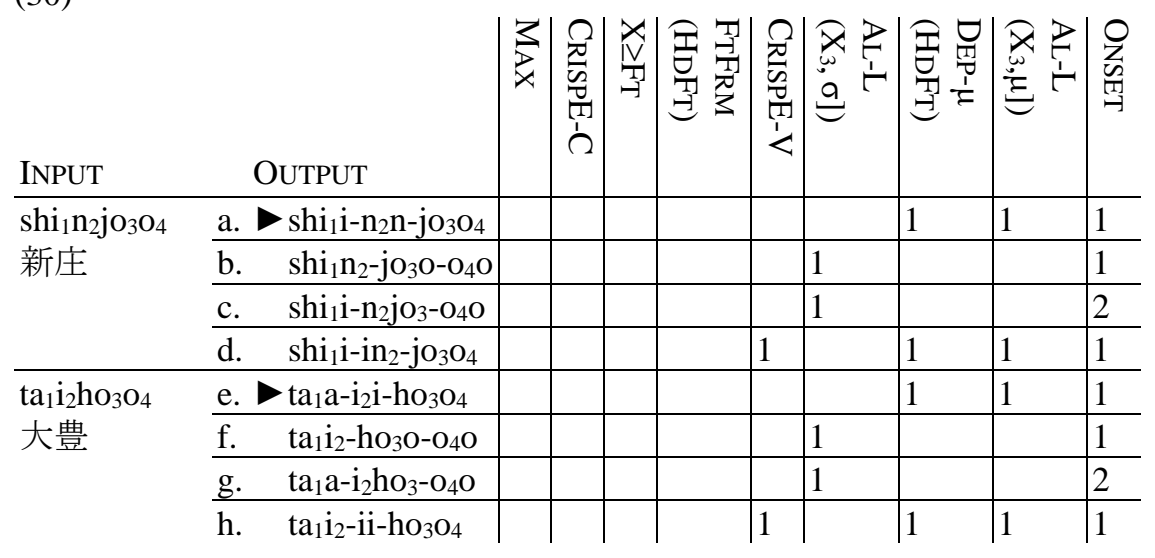

A LLLL-name like kiyohara assigns only the first mora to $\mathrm{X}_{1}$ and applies lengthening here, not in $\mathrm{X}_{2}$ because of DEP- $\mu$ (HDFT) (31a) vs. (31b).

\begin{tabular}{|c|c|c|c|c|c|c|c|c|c|c|c|}
\hline INPUT & OUTPUT & $\vec{x}$ & 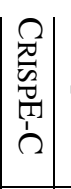 & 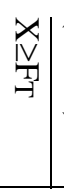 & 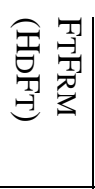 & 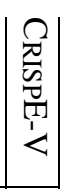 & 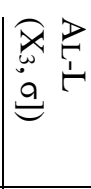 & 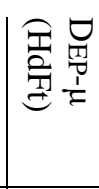 & 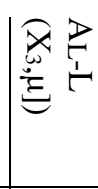 & & $\mid \begin{array}{l}\underset{T}{T} \\
\frac{1}{R} \\
\frac{1}{7}\end{array}$ \\
\hline kiyohara & a. $>$ kii-yoha-raa & & & & & & & & & & 2 \\
\hline 清原 & b. kiyo-haa-raa & & & & & & & 1 & & & 2 \\
\hline & $\begin{array}{ll}\text { c. } & \text { kii-yoo-hara } \\
\end{array}$ & & & & & & 1 & 1 & 1 & & 2 \\
\hline & d. $\quad$ kiyo-hara-aa & & & & & 1 & 1 & & 1 & 1 & 2 \\
\hline & e. kiyoha-raa-aa & & & & & 1 & 1 & 1 & 1 & 1 & 3 \\
\hline
\end{tabular}

But lengthening in $\mathrm{X}_{2}$ is not absolutely ruled out and indeed found when a higher-ranking constraint is at stake. This is shown by a $4 \mu$-name like kurain, whose syllabification we take to be ku.ra.in (see (9) above): (32a) kuu-raa-in beats (32b) kuu-rai-nn because of ALIGN-LEFT $\left.\left(\mathrm{X}_{3}, \sigma\right]\right)$, which crucially dominates DeP$\mu(\mathrm{HDFT})$ and $\left.\mathrm{AL}-\mathrm{L}\left(\mathrm{X}_{3}, \mu\right]\right)^{7}$

\begin{tabular}{|c|c|c|c|c|c|c|c|c|c|c|}
\hline INPUT & OUTPUT & $\left|\begin{array}{l}3 \\
⿱ 亠 乂 \\
x\end{array}\right|$ & 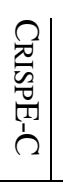 & 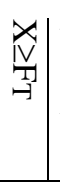 & 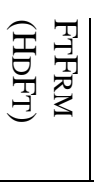 & $\begin{array}{l}\Omega \\
\pi \\
0 \\
0 \\
0 \\
1 \\
< \\
<\end{array}$ & 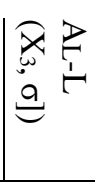 & 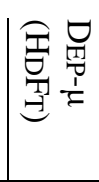 & 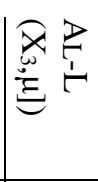 & $\mid \begin{array}{l}0 \\
Z \\
\text { 壆 } \\
\end{array}$ \\
\hline kurain & a. kuu-raa-in & & & & & & & 1 & 1 & 1 \\
\hline \multirow[t]{5}{*}{ Klein } & b. kuu-rai-nn & & & & & & 1 & & & 1 \\
\hline & c. kura-ii-nn & & & & & & 1 & 1 & & 2 \\
\hline & d. $\quad$ kura-in-nn & & 1 & & & & 1 & & 1 & 2 \\
\hline & e. kura-ii-in & & & & & 1 & 1 & 1 & 1 & 2 \\
\hline & f. $\quad$ kuu-uu-rain & & & & & 1 & & 2 & 1 & 1 \\
\hline
\end{tabular}

In (33) the winner (33a) joo-oji-maa beats (33b) joo-jii-maa because it avoids lengthening within the head foot $X_{2}$, at the cost of lengthening in $X_{1}$ and an onset violation. ${ }^{8}$

\footnotetext{
7 But kuu-rai-nn is another possible (if less preferred) output, so there might be some variability in the ranking between AL- $L\left(X_{3}, \sigma\right]$ and one or both of its dominated constraints.

8 The winner is (33a), which distributes the two $o$-moras over $\mathrm{X}_{1}$ and $\mathrm{X}_{2}$, and not the homonymous (33c), which keeps both $o$-moras within $\mathrm{X}_{1}$ but has gratuitous violations of CRISPE-V and DEP- $\mu(\mathrm{HDFT})$.
} 


\begin{tabular}{|c|c|c|c|c|c|c|c|c|c|c|}
\hline INPUT & OUTPUT & $\left|\begin{array}{l}3 \\
3\end{array}\right|$ & 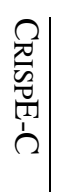 & 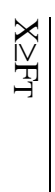 & 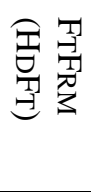 & 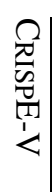 & $\mid \begin{array}{ll}x & D \\
0 & 1 \\
0 & -1\end{array}$ & 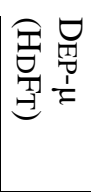 & $\mid \begin{array}{ll}\not{x} & D \\
0 & I \\
E & -1\end{array}$ & $\mid \begin{array}{l}0 \\
z \\
2 \\
\text { 留 }\end{array}$ \\
\hline \multirow{7}{*}{$\begin{array}{l}\mathrm{jo}_{1} \mathrm{O}_{2} \mathrm{ji}_{3} \mathrm{ma}_{4} \\
\text { 城島 }\end{array}$} & a. $-\mathrm{jo}_{1} \mathrm{O}-\mathrm{O}_{2} \mathrm{ji}_{3}-\mathrm{ma}_{4} \mathrm{a}$ & & & & & & & & & 1 \\
\hline & b. $\quad \mathrm{jo}_{1} \mathrm{O}_{2}-\mathrm{ji}_{3} \mathrm{i}-\mathrm{ma}_{4} \mathrm{a}$ & & & & & & & 1 & & \\
\hline & c. $\quad \mathrm{jo}_{1} \mathrm{O}_{2}-\mathrm{oji}_{3}-\mathrm{ma}_{4} \mathrm{a}$ & & & & & 1 & & 1 & & 1 \\
\hline & d. $\quad \mathrm{jo}_{1} \mathrm{o}_{2} \mathrm{ji}_{3}-\mathrm{ii}-\mathrm{ma}_{4} \mathrm{a}$ & & & & & & & 2 & & 1 \\
\hline & e. $\quad \mathrm{jo}_{1} \mathrm{O}_{2}-\mathrm{ji}_{3} \mathrm{ma}_{4}-\mathrm{aa}$ & & & & & 1 & 1 & & 1 & 1 \\
\hline & f. $\quad \mathrm{jo}_{1} \mathrm{O}_{2} \mathrm{ji}_{3}-\mathrm{ma}_{4} \mathrm{a}-\mathrm{aa}$ & & & & & 1 & 1 & 1 & 1 & 1 \\
\hline & g. $\quad \mathrm{X}-\mathrm{jo}_{1} \mathrm{O}_{2} \mathrm{ji}_{3}-\mathrm{ma}_{4} \mathrm{a}$ & & & 1 & & & & & & \\
\hline
\end{tabular}

Recapitulating the crucial interactions, we compare the derivations for ichiroo and joojima in (34).

\begin{tabular}{|c|c|c|c|c|c|}
\hline & INPUT & OUTPUT & $\left|\begin{array}{c}\Omega \\
\pi \\
0 \\
0 \\
1 \\
< \\
<\end{array}\right|$ & 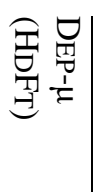 & $\mid \begin{array}{l}0 \\
Z \\
\text { 足 } \\
\text { 罗 }\end{array}$ \\
\hline \multirow[t]{2}{*}{ LLH } & $\mathrm{i}_{1} \mathrm{chi}_{2} \mathrm{rO}_{3} \mathrm{O}_{4}$ & a. $\mathrm{i}_{1} \mathrm{i}-\mathrm{chi}_{2} \mathrm{i}-\mathrm{rO}_{3} \mathrm{O}_{4}$ & & 1 & 1 \\
\hline & イチロー & b. $\quad \mathrm{i}_{1} \mathrm{i}-\mathrm{ichi}_{2}-\mathrm{rO}_{3} \mathrm{O}_{4}$ & 1 & & 2 \\
\hline \multirow[t]{2}{*}{ HLL } & $\mathrm{jo}_{1} \mathrm{O}_{2} \mathrm{ji}_{3} \mathrm{ma}_{4}$ & c. $\quad \mathrm{jo}_{1} \mathrm{O}_{2}-\mathrm{ji}_{3} \mathrm{i}-\mathrm{ma}_{4} \mathrm{a}$ & & 1 & \\
\hline & 城島 & d. $\mathrm{jo}_{1} \mathrm{O}-\mathrm{O}_{2} \mathrm{ji}_{3}-\mathrm{ma}_{4} \mathrm{a}$ & & & 1 \\
\hline
\end{tabular}

The candidate $i$-chii-roo bests $i$-ichi-roo because CRISPE-V > DEP- $\mu$ (HDFT). But, as we just saw in (33), joo-oji-maa bests joo-jii-maa because CRISPE-V is not involved, and DEP- $\mu(\mathrm{HDFT})>>\mathrm{ONSET}$. The same kind of same interaction is found in the derivation of the $5 \mu$-name oosutin $\rightarrow$ oo-osu-tin in (35).

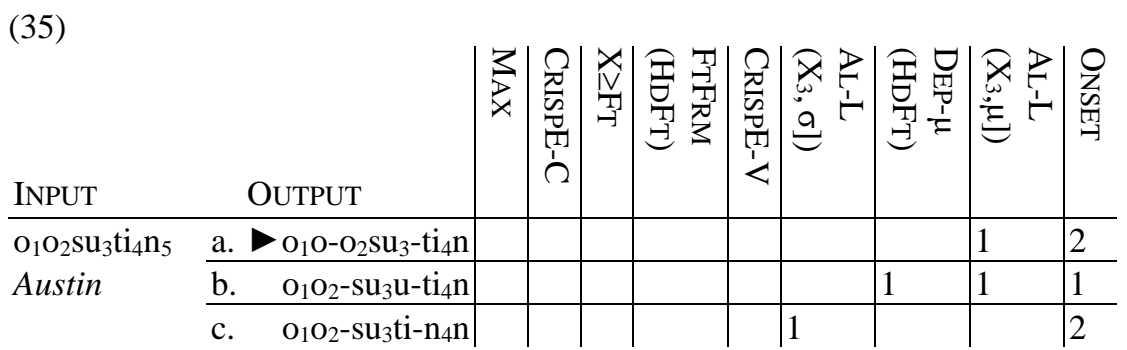

The 5 $\mu$-name doddoson in (36), whose kattobase-form is (36a) doo-oddo-son and not (36c) dod-doo-son, shows that spreading a consonant across X-boundaries is worse than spreading a vowel: CRISPEDGEC>CRISPEDGE-V.

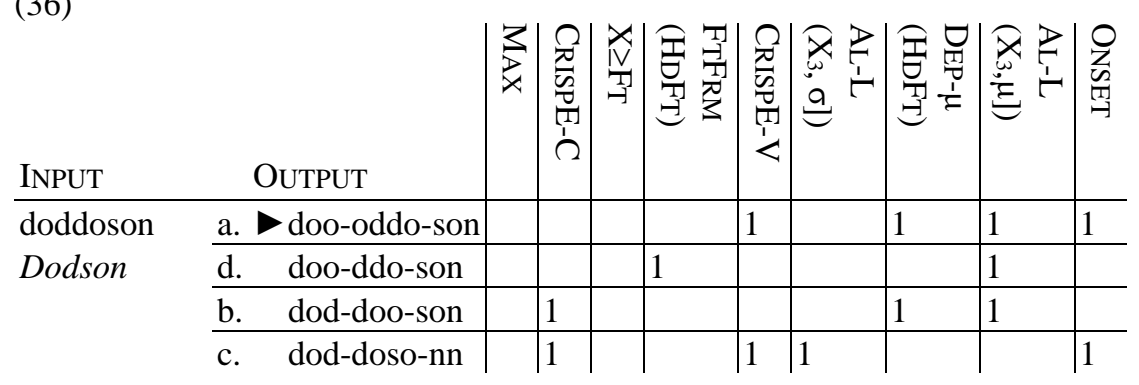


$5 \mu$-names (and longer names) clarify some issues that have so far not come up. First, there is the question of where "extra" material goes: moras that are not needed to fill each $\mathrm{X}$ with one foot. This issue is settled by (37): $\mathrm{X}_{1}$ is the place for extra material (makudo-naru-doo), not $\mathrm{X}_{2}$ (*maku-donaru-doo) or $\mathrm{X}_{3}$ (*maku-dona-

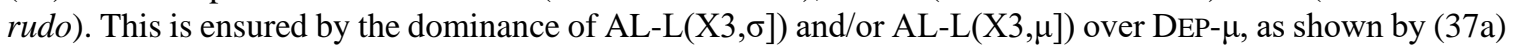
vs. $(37 \mathrm{c})$.

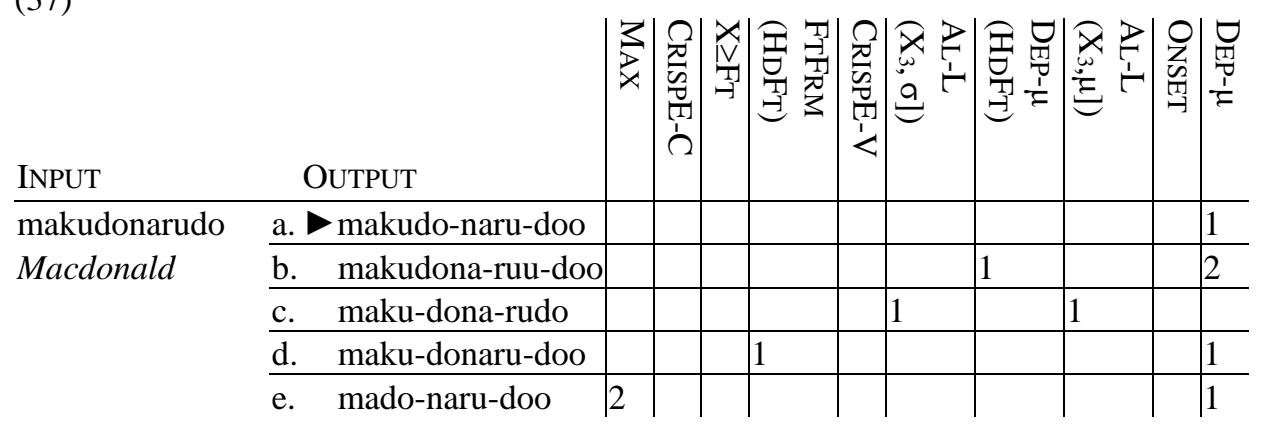

Next, there is the issue of assigning antepenult-penult sequences of different quantitative profiles ( $\mathrm{LH}, \mathrm{HH}$, LL, HL) to $X_{1}$ and $X_{2}$ (see (10)-(13) above). (38) shows that a heavy penult fills $X_{2}$ by itself.

\begin{tabular}{|c|c|c|c|c|c|c|c|c|c|c|c|}
\hline INPUT & OUTPUT & $\left|\begin{array}{c}3 \\
⿱ 亠 乂 \\
x\end{array}\right|$ & 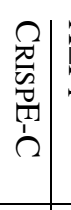 & 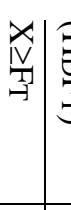 & 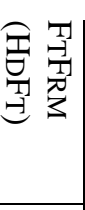 & $\left|\begin{array}{l}2 \\
\mathbb{Z} \\
\overline{5} \\
\bar{T} \\
1 \\
<\end{array}\right|$ & 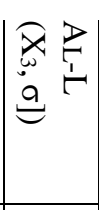 & 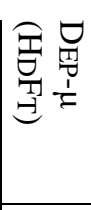 & 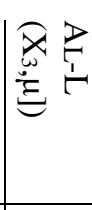 & 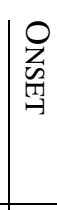 & \\
\hline desutoraade & a. $>$ desuto-raa-dee & & & & & & & & & & 1 \\
\hline ...LH... & b. $\quad$ desu-tora-ade & & & & & & 1 & & 1 & 1 & \\
\hline \multirow[t]{3}{*}{ Destrade } & c. desutora-aa-dee & & & & & 1 & & 1 & & 1 & 2 \\
\hline & d. $\quad$ desu-toraa-dee & & & 1 & 1 & & & & & & 1 \\
\hline & e. desu-tora-dee & 1 & & & & & & & & & 1 \\
\hline buraianto & f. $>$ burai-an-too & & & & & & & & & & 1 \\
\hline ...HН... & g. buu-raian-too & & & 1 & 1 & & & & & 1 & 2 \\
\hline Bryant & h. burai-anto-oo & & & & & 1 & 1 & & 1 & 1 & 2 \\
\hline
\end{tabular}

In (39), we see that a light penult is assigned to $X_{2}$ together with the antepenult, whether the antepenult is light or heavy. ${ }^{9}$

\begin{tabular}{|c|c|c|c|c|c|c|c|c|c|c|}
\hline INPUT & OUTPUT & $\left|\begin{array}{l}3 \\
2\end{array}\right|$ & 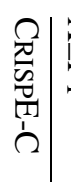 & 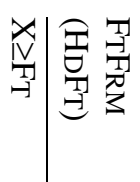 & $\left|\begin{array}{c}\Omega \\
\pi \\
\sqrt[\pi]{2} \\
0 \\
\mathbb{1} \\
< \\
<\end{array}\right|$ & 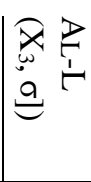 & 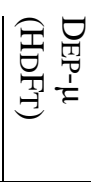 & 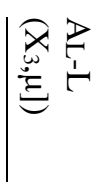 & 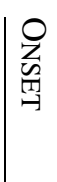 & 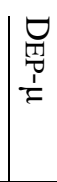 \\
\hline makudonarud & a. makudo-naru-doo & & & & & & & & & 1 \\
\hline Macdonald & b. makudona-ruu-doo & & & & & & 1 & & & 2 \\
\hline & c. maku-dona-rudo & & & & & 1 & & 1 & & \\
\hline & d. maku-donaru-doo & & & 1 & & & & & & 2 \\
\hline & e. mado-naru-doo & 2 & & & & & & & & |1 \\
\hline
\end{tabular}

\footnotetext{
${ }^{9}$ The fact that the HL sequence baato is assigned to $\mathrm{X}_{2}$ is the motivation for admitting the uneven trochee HL as a quantitative trochee in Japanese. It remains to be seen whether it is possible to find an alternative analysis which conforms to the standard view going back to Poser $(1984 ; 1990)$ that admits only the bimoraic trochee.
} 


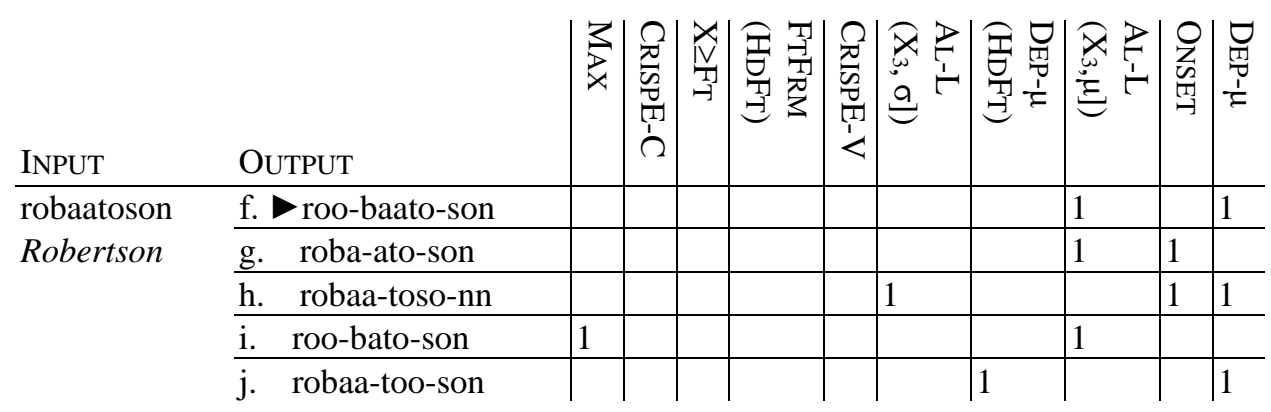

Recapitulating, we juxtapose the derivations for makudonarudo, boochaado, robaatoson, and desutoraade in (40), showing only the crucial constraint interactions.

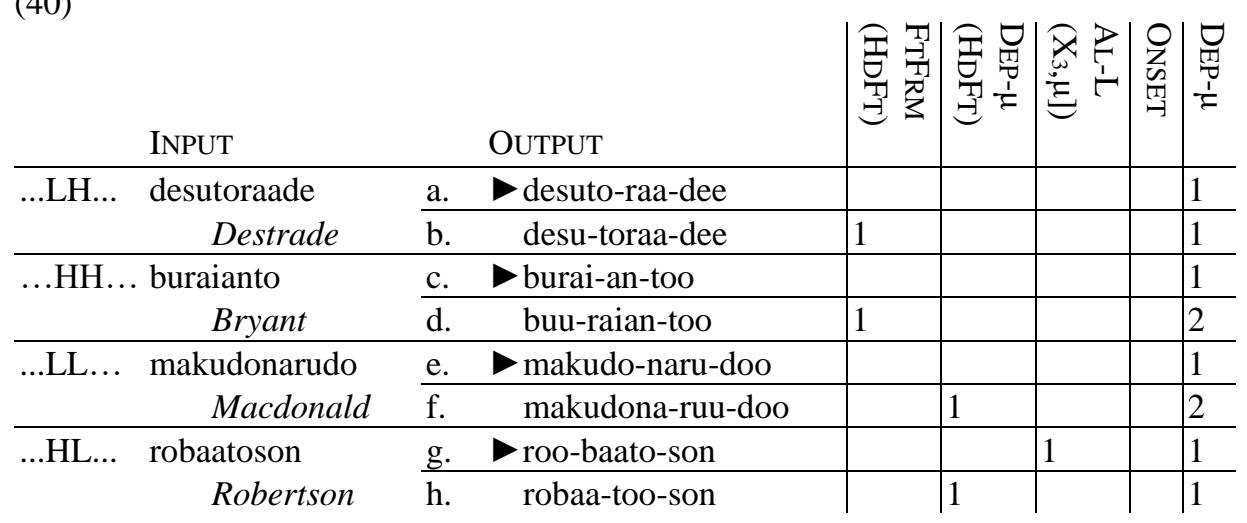

\section{Summary and conclusion}

We summarize by first assembling the evidence for all constraint rankings. The overall system is repeated in (41).

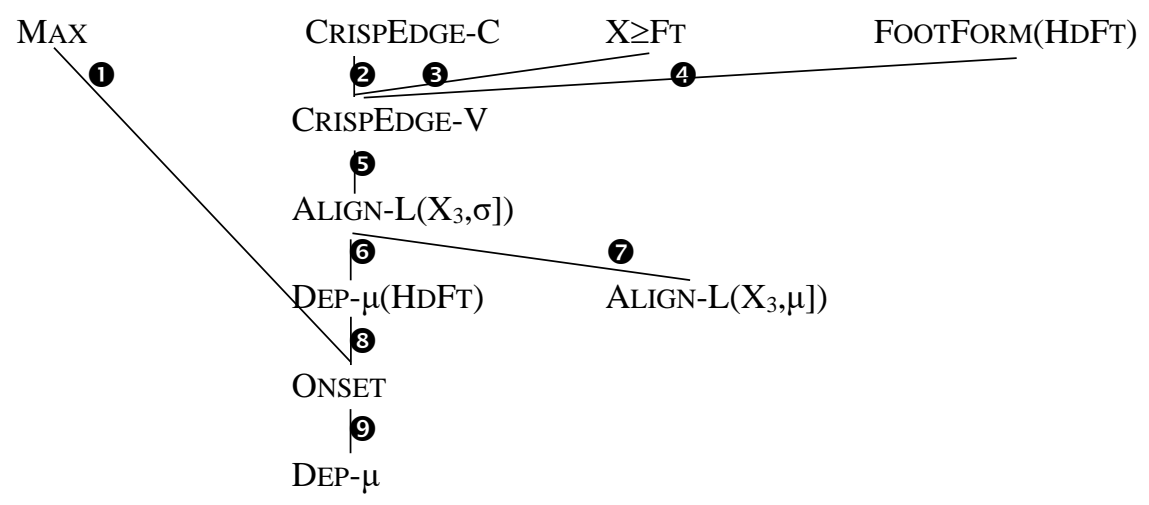

In (42), we present the evidence for each of the labeled ranking relation (produced with the help of OTWorkplace (Prince et al. 2015)). Crucial W(inner) L(oser) pairs justifying a particular ranking are given in bold. "W" in a constraint column means that the constraint prefers the winner; "L" means that the constraint prefers the loser. What is important here is the core of OT ranking logic: In order for the winner to defeat a given loser, it must do better on the highest-ranking constraint that distinguishes the two. 


\begin{tabular}{|c|c|c|c|c|c|c|c|c|c|c|c|c|}
\hline INPUT & WINNER & LOSER & $\underset{x}{3}$ & 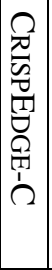 & \begin{tabular}{l}
$x$ \\
$v$ \\
$\frac{1}{1}$ \\
0 \\
0 \\
\hdashline
\end{tabular} & 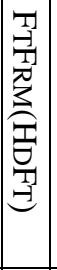 & 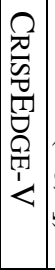 & 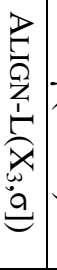 & 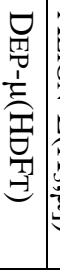 & 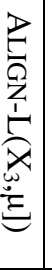 & 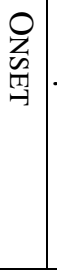 & 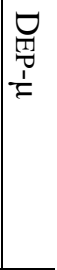 \\
\hline (1) ogasawara & oga-sawa-raa & gaa-sawa-raa & W & & & & & & & & $\mathbf{L}$ & W \\
\hline \begin{tabular}{l|l}
2 & son
\end{tabular} & soo-oo-nn & soo-nn-nn & & $\mathbf{W}$ & & & $\mathbf{L}$ & & $\mathrm{L}$ & W & & \\
\hline \begin{tabular}{l|l}
3 & ri
\end{tabular} & rii-ii-ii & rii-X-ii & & & $\mathbf{W}$ & & $\mathbf{L}$ & & $\mathrm{L}$ & & $\mathrm{L}$ & $\mathrm{L}$ \\
\hline \begin{tabular}{|l|l|}
4 & doddoson \\
\end{tabular} & doo-oddo-son & doo-ddo-son & & & & $\mathbf{W}$ & $\mathbf{L}$ & & $\mathrm{L}$ & & $\mathrm{L}$ & $\mathrm{L}$ \\
\hline \begin{tabular}{|l|l|}
5 & etoo
\end{tabular} & ee-too-oo & ee-ee-too & & & & & $\mathbf{W}$ & $\mathbf{L}$ & W & $\mathrm{W}$ & & \\
\hline 67 kurain & kuu-raa-in & kuu-rai-nn & & & & & & $\mathbf{W}$ & $\mathbf{L}$ & $\mathrm{L}$ & & \\
\hline 8 joojima & joo-oji-maa & joo-jii-maa & & & & & & & $\mathbf{W}$ & & $\mathbf{L}$ & \\
\hline \begin{tabular}{l|l}
9 & robaatoson
\end{tabular} & roo-baato-son & roba-ato-son & & & & & & & & & $\mathbf{W}$ & $\mathbf{L}$ \\
\hline
\end{tabular}

In conclusion, the OT-analysis, with its ranked and violable constraints, has succeeded in folding what appeared to be a set of separate rules depending on the length of the input into a single unified constraint system with a single ranking, where the length of the input exerts its influence by resulting in different violation profiles in outputs, and does not require separate rules for inputs of different length. Besides the alignment constraints specific to the baseball chant, the other constraints are uncontroversial faithfulness (MAX/DEP) constraints and structural markedness constraints (on foot/syllable structure and their edges). Among the many remaining questions, however, the most important perhaps is why the desired foot form in $\mathrm{X}_{2}$ is the quantitative trochee that admits also the trimoraic HL-foot, and not the bimoraic trochee otherwise firmly grounded in the phonology of Japanese. It is clear that much work remains to be done-in particular in grounding the constraints better in the prosodic system of the language.

\section{Appendix}

\begin{tabular}{l|l|l|l}
$\begin{array}{l}\text { Romanized } \\
\text { transcription }\end{array}$ & Original Name & $\begin{array}{l}\text { Katakana } \\
\text { transcription }\end{array}$ & Former/Main Team \\
\hline arekkusu & Alex Ochoa & アレックス & Chunichi Dragons \\
\hline baanzu & Jacob Barnes & バーンズ & Milwaukee Brewers \\
\hline baasu & Randy Bass & バース & Hanshin Tigers \\
\hline bansuroo & Vance Law & バンスロー & Chunichi Dragons \\
\hline boochaado & Joe Borchard & ボーチャード & Chicago White Sox \\
\hline buraianto & Kris Bryant & ブライアント & Chicago Cubs \\
\hline buranboo & Cliff Brumbaugh & ブランボー & Orix Buffaloes \\
\hline chen & 陳 & チェン & Chunichi Dragons \\
\hline deshinsei & Doug DeCinces & デシンセイ & Yakult Swallows \\
\hline desutefaano & Benny Distefano & デステファーノ & Chunichi Dragons \\
\hline desutoraade & Orestes Destrade & デストラーデ & Seibu Lions \\
\hline doddoson & Pat Dodson & ドッドソン & Kintetsu Buffaloes \\
\hline etoo & 江藤 & エトー & Chunichi Dragons \\
\hline ferunandesu & José Fernández & フェルナンデス & Florida Marines \\
\hline furanko & Julio Franco & フランコ & Lotte Marines \\
\hline furanshisuko & Juan Francisco & フランシスコ & Yomiuri Giants \\
\hline genda & 源田 & ゲンダ & Seibu Lions \\
\hline gengoroomaru & 源五郎丸 & ゲンゴローマル & Hanshin Tigers \\
\hline gonzaresu & Dicky González & ブンザレス & Yakult Swallows \\
\hline
\end{tabular}




\begin{tabular}{|c|c|c|c|}
\hline hansen & Bob Hansen & ハンセン & Seibu Lions \\
\hline ichiroo & イチロー & イチロー & Seattle Mariners \\
\hline infante & Omar Infante & インファンテ & Detroit Tigers \\
\hline joojima & 城島 & ジョージマ & Hanshin Tigers \\
\hline joonzu & Garrett Jones & ジョーンズ & Yomiuiri Giants. \\
\hline kai & 甲斐 & カイ & Softbank Hawks \\
\hline kakefu & 掛布 & カケフ & Hanshin Tigers \\
\hline kitabeppu & 北別府 & キタベップ & Hiroshima Carp \\
\hline kiyohara & 清原 & キヨハラ & Yomiuri Giants \\
\hline kobayakawa & 小早川 & コバヤカワ & Yakult Swallows \\
\hline kontorerasu & José Contreras & コントレラス & Chicago Whitesox \\
\hline kurain & Phil Klein & クライン & DeNA BayStars \\
\hline kuromati & Warren Cromartie & クロマティ & Yomiuri Giants \\
\hline kuruun & Marc Kroon & クルーン & Yomiuri Giants \\
\hline mahoomuzu & Pat Mahomes & マホームズ & DeNA Baystars \\
\hline makanarutii & Paul McAnulty & マカナルティー & San Diego Padres \\
\hline makudonarudo & Bob Macdonald & マクドナルド & Hanshin Tigers \\
\hline ochiai & 落合 & オチアイ & Chunichi Dragons \\
\hline ogasawara & 小笠原 & オガサワラ & Yomiuri Giants \\
\hline oguribii & Ben Oglivie & オグリビー & Kintetsu Buffaloes \\
\hline oosutin & Tyler Austin & オースティン & New York Yankees \\
\hline ootani & 大谷 & オータ二 & LA Angels \\
\hline ootomo & 大友 & オートモ & Yomiuri Giants \\
\hline ri & 李 & リ & Chunichi Dragons. \\
\hline rii & Leon Lee & リー & Lotte Orions \\
\hline rinaresu & Omar Linares & リナレス & Chunichi Dragons \\
\hline robaatoson & David Robertson & ロバートソン & New York Yankees \\
\hline saiki & 才木 & サイキ & Hanshin Tigers \\
\hline seginooru & Fernando Seguignol & セギノール & Nippon Ham \\
\hline shinjoo & 新庄 & シンジョー & Hanshin Tigers \\
\hline shipin & Sipin & シピン & Yomiuri Giants \\
\hline son & 宣 & ソン & Chunichi Dragons \\
\hline taihoo & 大豊 & タイホー & Chunichi Dragons \\
\hline $\operatorname{tani}$ & 谷 & タ二 & Yomiuri Giants \\
\hline tatsunami & 立浪 & タツナミ & Chunichi Dragons \\
\hline wiruson & George Wilson & ウィルソン & Seibu Lions \\
\hline yano & 矢野 & ヤノ & Hanshin Tigers \\
\hline
\end{tabular}

\section{References}

Ito, Junko, and Armin Mester. 1999. Realignment. In Proceedings of the Utrecht Workshop on Prosodic Morphology, ed. René Kager, Harry van der Hulst, and Wim Zonneveld, 188-217. Cambridge: Cambridge University Press.

Ito, Junko, and Armin Mester. 2018. Tonal alignment and preaccentuation. Journal of Japanese Linguistics 34(2): 195222.

Kubozono, Haruo. 2015. Introduction to Japanese phonetics and phonology. In Handbook of Japanese Phonetics and Phonology, ed. Haruo Kubozono, 1-40. Berlin/Boston/Munich: De Gruyter, Mouton.

Liberman, Mark. 1975. The Intonational System of English. Doctoral dissertation, Cambridge, Mass.: MIT. [Published in 1979, New York and London: Garland Publishing].

Poser, William J. 1984. Hypocoristic formation in Japanese. In Proceedings of WCCFL 3, ed. Mark Cobler, Suzannah MacKaye, and Michael T. Wescoat, 218-229. Stanford: Stanford Linguistic Association.

Poser, William J. 1990. Evidence for foot structure in Japanese. Language 66(1): 78-105. 
Prince, Alan S., and Paul Smolensky. 1993. Optimality Theory: Constraint Interaction in Generative Grammar. Brunswick, New Jersey, and Boulder, Colorado: Rutgers University and University of Colorado, Boulder. [Published in 2004, Malden, MA: Wiley-Blackwell].

Prince, Alan S., Bruce Tesar, and Nazarré Merchant. 2015. OTWorkplace Installer Package. Http://ruccs.rutgers.edu/images/personal-alan-prince/otworkplace/OTWorkplaceInstallerPackage_ver12.zip. Tanaka, Shin'ichi. 2008. Rizumu/akusento no "yure" to on 'in/keitai-kouzou [Fluctuation in rhythm and accent and phonological and morphological structure]. Tokyo, Japan: Kurosio Publishing.

Vance, Timothy J. 2008. The Sounds of Japanese. Cambridge, U.K.: Cambridge University Press. 